\title{
Determinants of farmers' access to microcredit from cooperative societies in Ondo state, Nigeria
}

\author{
A. Kolapo*iD, A.S. Ogunleye, A.D. Kehinde and A.A. Adebanke \\ Received 23 July 2021, Revised 23 November 2021, Accepted 20 December 2021, Published online 31 December 2021
}

\begin{abstract}
A B S T R A C T
The study examined the determinants of farmers' access to microcredit from cooperative societies in Ondo state. A multistage sampling technique was used to obtain data from 100 respondents. Primary data was collected for the purpose of the study. We used descriptive statistics and logit regression model to analyses the data collected. Result showed that the farmers were mostly male farmers (64\%) while majority of the farmers had a mean age of $44.10 \pm 14.70$. It was also revealed that consumer cooperative society, producer cooperative society, marketing cooperative society, cooperative farming society and credit and thrift cooperative society were the major forms of cooperative used by the farmers. The result also shows that age, marital status, farm size, farming experience, credit from another source and number of years in the cooperative significantly influenced farmers' access to microcredit from cooperative society.
\end{abstract}

Keywords: Determinants, Farmers, Microcredit, Cooperative societies and Ondo State

Department of Agricultural Economics, Faculty of Agriculture, Obafemi Awolowo University, Ile-Ife, Nigeria

*Corresponding author’s email: kolapoadetomiwa@gmail.com (A. Kolapo)

Cite this article as: Kolapo, A., Ogunleye, A.S., Kehinde, A.D. and Adebanke, A.A. 2021. Determinants of farmers' access to microcredit from cooperative societies in Ondo state, Nigeria. Int. J. Agril. Res. Innov. Tech. 11(2): 103-107. https://doi.org/10.3329/ijarit.v11i2.57262

\section{Introduction}

In Nigeria, agriculture is the largest non-oil export earner and major employer of labour and a key contributor to wealth creation, contributing 41.21\% of Gross Domestic Product (GDP) and mitigating poverty (NPC, 2006). The existence of an uncertain and threatened oil economy has renewed the focus on Agriculture as holding the key to national development compelling a solution to the challenge of rural farmers' access to microcredit facilities and their full participation in sustainable agricultural development. The growth in the economy of Nigeria is partially based on the contribution of Agriculture. Agriculture has also contributed to the economy by: Providing surplus labour for the industrial sector; providing market for goods produced by secondary sector; supplying domestic savings for industrial/secondary investment; supply of foreign exchange earnings gotten from export of agricultural products. It has also helped to increase the stability of the economy, improve food security and it has helped farmers especially the small-scaled/rural farmers to have access to inputs. However, for agriculture to contribute to national development, farmers must have the required input to invest. Most farmers in the rural area have inadequate resources to get the required input such as seeds, fertilizers, chemicals and credit facilities. One of the ways farmers can have access to these inputs is to form a group and pool their resources together for effective use. There are so many factors that determine a farmer's access to credit and they include income level, distance to credit sources, assets owned, repayment flexibility, household labour, gender, educational level, credit information and farm size. Credit allocation and utilization for agricultural production subsequently promotes productivity thereby improving food security status of the community (Alfred and Corntassel, 2005). However, the availability of credit facilities is a major prerequisite to agricultural development including increased agricultural productivity. However, one of the major factors that determine credit allocation in the rural area is the socio-economic characteristics of the farmer. There are factors, which influence farmers' access to credit from cooperative societies. As stated by Emerole et al. (2013), access to credit from cooperative societies is dependent on the number of years of farming by the farmer, farming as primary occupation, farmers' membership to cooperative groups and 
farmers' savings in the cooperative society. In addition, denial of loans from formal sources also influenced the farmers' access to loans from the cooperative society. It is evident that different works have been carried out on utilization of credit, credit accessibility and socio-economic effects on credit access. However, there is still need to carry out effective study to find out the factors that influence farmers' access to microcredit in Ondo state.

\section{Materials and Methods}

\section{Study area}

The research study was carried out in Ondo State, Nigeria. Ondo state was created in 1976 out of the former Western State. Ondo state is bounded on the east and west by Delta/Edo and Ogun/Osun states respectively. Ondo state occupies about $15,000 \mathrm{~km}^{2}$ in land mass with an approximate population of about 3,441,924. Ondo State comprised of 18 Local Government Areas. The people of the state are mostly Yoruba, although other Nigerians and foreign nationals equally live in the state. Agriculture is the mainstay of the economy of the people of Ondo state. The main agricultural products are cotton and tobacco, cocoa, rubber, timber, palm oil and kernels are cultivated for export throughout the state.

\section{Sampling procedure and sampling size}

We used a multistage sampling procedure in the selection of the respondents. Farmers were selected using multi-stage random sampling technique since majority of the populace are involved in farming activities. At the first stage, we selected five (5) LGAs from the eighteen (18) LGAs. The, the second stage comprised of a random selection of three (3) villages from each of the LGAs. At the third stage, we selected randomly five farmers from each village. Therefore, one hundred (100) farmers were selected. We used a well-structured questionnaire to survey information from the respondents. The questionnaire captured important information on socio-economic characteristics of the respondents including age, household size, gender, education, farm size and farming experience. It also conveyed information on the forms of cooperative societies, the determinants of farmers' access to microcredit and constraints to access to microcredit by farmers among cooperative societies.

\section{Econometric technique}

Descriptive statistics

We used descriptive statistics to describe the socio-economic characteristics of the farmers surveyed. It was also used to profile the forms of cooperative society and identify constraints farmers face in accessing microcredit form cooperative societies.

\section{Logit regression}

We used binary logit regression to analyze the determining factors that influence farmers' access to microcredit. The explicit form of the binary logit model according to Mohamed (2003) is presented below:

$\operatorname{logit} P(Y)=\beta_{o}+\sum \beta_{i} X_{i}+\mu$

Where,

$\mathrm{Y}=$ credit access, $\mathrm{X}_{\mathrm{i}}=$ determinants of credit access, $\beta_{\mathrm{o}} \beta_{1}=$ coefficients, $\mu=$ error term

$\mathrm{Y}=\beta \mathrm{O}+\beta_{1} \mathrm{X}_{1}+\beta_{2} \mathrm{X}_{2}+\beta_{3} \mathrm{X}_{3}+\beta_{4} \mathrm{X}_{4}+\beta_{5} \mathrm{X}_{5}+$ $\beta 6 \mathrm{X} 6+\beta 7 \mathrm{X}_{7}+\beta 8 \mathrm{X} 8+\beta 9 \mathrm{X} 9+\beta 10 \mathrm{X} 10+\mathrm{e}$

Where $Y=$ (" 1 " if respondent has access to credit and " $\mathrm{O}$ " if respondent has no access to credit).

$\mathrm{X}_{1}=$ Age (in years)

$\mathrm{X}_{2}=$ Marital Status (married $=1$; otherwise $=0$ )

$\mathrm{X}_{3}=$ financial status

$\mathrm{X}_{4}=$ Years of Education

$\mathrm{X}_{5}=$ farming experience (in years)

$\mathrm{X}_{6}=$ farm size (in hectares)

$\mathrm{X}_{7}=$ credit from another source (yes $=1 ;$ no $=0$ )

$\mathrm{X} 8=$ number years in the cooperative society (in years)

$\mathrm{X} 9=$ savings in the cooperative society (in naira)

$\mathrm{X} 10=$ interest rate $(\%) \mathrm{e}=$ error term

\section{Empirical Results and Discussion}

\section{Socio-economic characteristics}

The socio-economic distributions of the farmers in Table 1 indicate that majority (64.0\%) of the respondents were male. This implies that majority of the farmers were male. This is in conformity with Ololade and Olagunju (2013). This might be because of the intensive labour requirement nature in agricultural farming operations. We found the average age of the farmers to be 44 years. This implied that they were in their productive and active age. From Table 1, majority (68.0\%) of the farmers were married with household size of between 6 to 10 members. The results further showed that farmers have farm sizes of between 1 to 5 ha. This implied that the farmers were smallholder farmers. We also found that majority $(81.0 \%)$ of farmers had some forms of education. This indicates that the farmers are literate and thus can read and write. The result revealed that the majority (39.0\%) of the farmers had farming experience of between 5-10 years and thus implying that the farmers had a reasonable year of experience in farming. 
Table 1. Socio-economic characteristics of the farmers.

\begin{tabular}{|c|c|c|}
\hline Variables Age (in years) & Frequency & Percentage \\
\hline $20-30$ & 25 & 25.0 \\
\hline $31-40$ & 43 & 43.0 \\
\hline $41-50$ & 17 & 17.0 \\
\hline Above 51 & 15 & 15.0 \\
\hline Total & 100 & 100.0 \\
\hline Mean & 44.10 & \\
\hline S.D & 14.70 & \\
\hline \multicolumn{3}{|l|}{ Gender } \\
\hline Male & 64 & 64.0 \\
\hline Female & 36 & 36.0 \\
\hline Total & 100 & 100.0 \\
\hline \multicolumn{3}{|l|}{ Marital Status } \\
\hline Single & 20 & 20.0 \\
\hline Married & 68 & 68.0 \\
\hline Divorced & 5 & 5.0 \\
\hline Widowed & 7 & 7.0 \\
\hline Total & 100 & 100.0 \\
\hline \multicolumn{3}{|l|}{ Household size } \\
\hline $1-5$ & 4 & 4.0 \\
\hline $6-10$ & 76 & 76.0 \\
\hline Over 10 & 19 & 19.0 \\
\hline Total & 99 & 99.0 \\
\hline \multicolumn{3}{|l|}{ Educational level } \\
\hline No formal education & 19 & 19.0 \\
\hline Primary education & 30 & 30.0 \\
\hline Secondary education & 34 & 34.0 \\
\hline Tertiary education & 17 & 17.0 \\
\hline Total & 100 & 100.0 \\
\hline \multicolumn{3}{|l|}{ Farming experience } \\
\hline Below 5 years & 33 & 33.0 \\
\hline $5-10$ years & 39 & 39.0 \\
\hline Above 10 years & 28 & 28.0 \\
\hline Total & 100 & 100.0 \\
\hline \multicolumn{3}{|l|}{ Farm size } \\
\hline 1-5 hectares & 62 & 62.0 \\
\hline 6-10 hectares & 24 & 24.0 \\
\hline Above 10 hectares & 5 & 5.0 \\
\hline Not specified & 9 & 9.0 \\
\hline Total & 100 & 100.0 \\
\hline
\end{tabular}

Source: Field Survey, 2019

Forms of cooperative used by the farmers

The forms of cooperative society in the study area was found out to be consumer cooperative (8\%), producer cooperative (28\%), marketing cooperative (4\%), cooperative farming society (33\%) and credit and thrift cooperative society (27\%). Majority of the farmers were in the cooperative farming society (Table 2). This implies that farmers have diverse cooperative societies to benefit from where they can source for capital and other agricultural inputs. In addition, these diverse cooperative societies can also help the farmers in the area of products marketing so the farmers can realize substantial income from the sales of their farm produce.

Table 2. Forms of cooperative in the study area.

\begin{tabular}{|l|c|c|}
\hline Forms of cooperative & Frequency & Percentage \\
\hline Consumer cooperatives & 8 & 8.0 \\
\hline Producer cooperative & 28 & 28.0 \\
\hline Marketing cooperative & 4 & 4.0 \\
\hline Cooperative farming society & 33 & 33.0 \\
\hline Credit and thrift society & 27 & 27.0 \\
\hline Total & 100 & 100.0 \\
\hline Source: Field survey, 2019 & & \\
\hline
\end{tabular}




\section{Determining factors affecting farmers' access to microcredit}

Table 3 shows the result of analysis of the logit model explaining the factors influencing farmers access to microcredit from cooperative societies with respect to age, household size, marital status, farming experience, educational level, farm size, credit from another source, number of years in the cooperative, savings in the cooperative, interest rate charged, financial status of the farmer and the gender of the farmer.

The result shows that age negatively and significantly at $5 \%$ level of probability influenced farmers access to credit from cooperative societies. This indicated that as farmers get older, the lower the likelihood of a farmer was accessing credit from the cooperative society. This is because as the farmer increases in age, his ability to bear risks diminishes thus affecting farmers opportunity of accessing credit from the cooperative society.

In addition, the coefficient of the marital status of the farmers is positively significant at $\mathrm{p}<0.10$. This indicates that marital status increases the likelihood of the farmers in having access to credit from the various cooperative societies they belong. This might be attributed to the fact that married farmers were considered to be responsible, hence they tends to be able to re-pay back their loan proceeds obtained from the cooperative societies.
The coefficient of the farming experience of the farmers was positive and significant at $\mathrm{p}<0.10$. This implies that farming experience increases the likelihood of farmers having access to credit from the cooperative societies.

The coefficient of the farm size was negatively significant at $1 \%$ level, which implies that the likelihood of the farmers accessing credits from the various cooperative societies decreases as farm size increases. Thus, farming experiences increases the likelihood of accessing credit from cooperative societies by $6.4 \%$.

The coefficient of credit from another source was positive and significant at $\mathrm{p}<0.05$. This implies that sourcing for credit from another source increases the likelihood of having access to credit from the cooperative society they belong. Their clean and adequate financial records from other sources might interest the cooperative societies to allow the farmers to access credit. The coefficient of the number of years the farmer has spent in the cooperative was positively significant at $\mathrm{p}<0.05$. This implies that the likelihood of farmers accessing credit from cooperative societies increases with the number of years they have spent in the cooperative. The adjusted $\mathrm{R}^{2}$ in the factors affecting access to credit is 0.2387 this implies that $23.87 \%$ of the determinants of farmers' access to microcredit from cooperative societies are explained by the independent variable.

Table 3. Factors influencing farmers' access to credit from cooperative societies.

\begin{tabular}{|l|c|c|}
\hline Variables & Coefficient & T-value \\
\hline Constant & $3.795^{* *}$ & 2.54 \\
\hline Age & $-0.012^{* *}$ & 2.33 \\
\hline Marital status & $0.770^{*}$ & 1.67 \\
\hline Household size & 0.157 & 0.57 \\
\hline Educational level & -0.706 & -0.44 \\
\hline Farming experience & $0.646^{*}$ & 1.68 \\
\hline Farm size & $-0.074^{* * *}$ & -2.79 \\
\hline Credit from another source & $1.224^{* *}$ & 2.08 \\
\hline Number of years in the cooperative & $1.578^{* *}$ & 2.52 \\
\hline Savings in the cooperative & 0.563 & 0.54 \\
\hline Interest rate charged & 0.017 & 0.11 \\
\hline Financial status & 0.862 & 1.47 \\
\hline
\end{tabular}

Source: Field Survey, $2019 R^{2}=0.2387 *$ significant at $10 \%{ }^{* *}$ significant at $5 \%{ }^{* * *}$ significant at $1 \%$ level.

Constraints to access to microcredit by farmers among the cooperative societies

The constraints facing farmers in accessing microcredit are identified and ranked in Table 4. Among the identified ranked constraints are inadequate credit size, late disbursement and collateral requirement, which had means of $1.99 \pm 0.906, \quad 1.80 \pm 0.902$ and $1.89 \pm 0.880$, respectively, which were the three major constraining factors of accessing credit by farmers from the cooperative society.

Inadequate credit size facing the farmers is also a constraint for them accessing credit from cooperative societies. This is consistent with the findings of Zywicki and Adamson (2007), that inadequate credit does not enable farmers to undertake efficient and effective methods of production to achieve production targets. 
Disbursing microcredit very late was the second identified constraint. Agricultural production is seasonal, thus, when credit is issued out to farmers late or after a production season, the money will gets rechanneled to other business which may not be necessarily agricultural production. This is in line with the studies of Asogwa et al. (2014).

Collateral requirement was the third identified constraints to microcredit access from cooperative societies. Although, the successful access to microcredit is highly dependent on collateral provided to avoid moral hazards. The situation thus becomes aggravated in situation where farmer does not possess any or required assets needed as collateral. Does lack of collateral requirement to accessing microcredit due to limited ownership and other useful production factors, hinder majority of the farmers' chance of access to microcredit.

Table 4. Constraints of accessing microcredit from cooperative societies.

\begin{tabular}{|l|c|c|c|c|c|}
\hline Identified constraint & Min. & Max. & Mean & Std. D & \multicolumn{2}{|c|}{ Rank } \\
\hline Inadequate Credit Size & 1 & 3 & 1.99 & 0.906 & $1^{\text {st }}$ \\
\hline Late Disbursement & 1 & 3 & 1.80 & 0.902 & $2^{\text {nd }}$ \\
\hline Collateral Requirement & 1 & 3 & 1.89 & 0.880 & $3^{\text {rd }}$ \\
\hline
\end{tabular}

Source: Field Survey, 2019.

\section{Conclusions}

The study concludes that majority of the farmers were male and were in their active years. It was also concluded that majority of the smallholder farmers were married and the household size of majority of the farmers was relatively large with an average size of 8 . Majority of the farmers were literate. The forms of cooperative society utilized by the farmers include consumer cooperative, producer cooperative, marketing cooperative, cooperative farming society, credit and thrift society. The determinants of farmers' access to microcredit from cooperative society were found to include age, marital status, farming experience, farm size credit from another source and number of years in the cooperative. This study also concluded that major constraints to access to microcredit by farmers among cooperative society were late disbursement, inadequate credit size and collateral requirement. It is recommended that younger farmers who are still agile should be encouraged to join cooperative societies so that they can have access to microcredit within their domain.

\section{References}

Alfred, T. and Corntassel, J. 2005. Being indigenous: resurgences against contemporary colonialism. Govt. Oppos. 40(4): $597-614$.

https://doi.org/10.1111/j.1477-7053.2005.00166.x
Asogwa, B.C., Abu, O. and Ochoche, G.E. 2014. Analysis of peasant farmers' access to agricultural credit in Benue state, Nigeria. British J. Econ. Manage. Trade. 4(10): 1525-1543.

Emerole, C.O., Nwachukwu, A.N., Anyiro, C.O., Osondu, C.K., Ibezim, G.M.C. and Jonah, N. 2013. Default risk and determinants of farmers' access to microcredit from cooperative societies in Abia State, Nigeria. Asian J. Agril. Ext. Econ. Soc. 3(1): 50-62.

Mohamed, K. 2003. Access to formal and quasiformal credit by smallholder farmers and artisanal fishermen. Research Report No. 03.6. Ministry of Agriculture, Natural Resources, Environment and Cooperation, Zanzibar, Tanzania. 53p.

NPC. 2006. Nigerian Population Census Report 2006. National Population Commission, Nigeria.

Ololade, R.A. and Olagunju, F.I. 2013. Determinants of access to credit among rural farmers in Oyo State, Nigeria. Glob. J. Sci. Front. Res. Agric. Vet. Sci. 13(2): 17-21.

Zywicki, T.J. and Adamson, J.D. 2007. The Law and Economics of Subprime Lending. George Mason University Law and Economics Research Network. University of Colorado Law Review. Vol. 80, No. 1, pp. 186. 